University of Nebraska - Lincoln

DigitalCommons@University of Nebraska - Lincoln

\title{
A CONTINUOUS CULTURE OF PLURIPOTENT FETAL HEPATOCYTES DERIVED FROM THE 8-DAY EPIBLAST OF THE PIG
}

Neil C. Talbot

United States Department of Agriculture

Caird E. Rexroad Jr.

United States Department of Agriculture

Anne M. Powell

United States Department of Agriculture, anne.powell@ars.usda.gov

Vernon G. Pursel

United States Department of Agriculture

Thomas J. Caperna

United States Department of Agriculture

See next page for additional authors

Follow this and additional works at: https://digitalcommons.unl.edu/usdaarsfacpub

Part of the Agricultural Science Commons

Talbot, Neil C.; Rexroad, Caird E. Jr.; Powell, Anne M.; Pursel, Vernon G.; Caperna, Thomas J.; Ogg, Sherry L.; and Nel, Neil D., "A CONTINUOUS CULTURE OF PLURIPOTENT FETAL HEPATOCYTES DERIVED FROM THE 8-DAY EPIBLAST OF THE PIG" (1994). Publications from USDA-ARS / UNL Faculty. 688. https://digitalcommons.unl.edu/usdaarsfacpub/688

This Article is brought to you for free and open access by the U.S. Department of Agriculture: Agricultural Research Service, Lincoln, Nebraska at DigitalCommons@University of Nebraska - Lincoln. It has been accepted for inclusion in Publications from USDA-ARS / UNL Faculty by an authorized administrator of DigitalCommons@University of Nebraska - Lincoln. 


\section{Authors}

Neil C. Talbot, Caird E. Rexroad Jr., Anne M. Powell, Vernon G. Pursel, Thomas J. Caperna, Sherry L. Ogg, and Neil D. Nel 


\title{
A CONTINUOUS CULTURE OF PLURIPOTENT FETAL HEPATOCYTES DERIVED FROM THE 8-DAY EPIBLAST OF THE PIG
}

\author{
NEIL C. TALBOT, CAIRD E. REXROAD, JR. ${ }^{1}$, ANNE M. POWELl, VERNON G. PURSEL, \\ THOMAS J. CAPERNA, SHERRY L. OGG, AND NEIL D. NEL ${ }^{2}$ \\ U.S. Department of Agriculture, Agricultural Research Service, Beltsville Agricultural Research Center, Gene Evaluation and Mapping \\ Laboratory, and Nonruminant Animal Nutrition Laboratory (T. J. C.), and Livestock and Poultry Sciences Institute, \\ Beltsville, Maryland 20705
}

(Received 24 January 1994; accepted 26 May 1994)

\begin{abstract}
SUMmarY
Continuous cultures of pluripotent parenchymal hepatocytes were derived from the epiblasts of 8-day-old pig blastocysts. The cells were polygonal and had phase-contrast dark, granular cytoplasm with prominent nuclei and nucleoli. These feeder-dependent cell cultures differentiated into large, multicellular, secretory, duct-like structures or formed small canaliculi between individual cells. Alternatively, the cells accumulated droplets that stained intensely with Oil Red 0 , a lipid-specific stain. Alpha-fetoprotein (AFP), albumin, and $\beta$-fibrinogen mRNAs were expressed as the cells differentiated in culture. Serum-free medium that was conditioned by the cells contained transferrin, AFP, and albumin. The growth and viability of the cells were inhibited by transforming growth factor $\beta 1$ (TGF $\beta 1$ ) at concentrations $\geq 1 \mathrm{ng} / \mathrm{ml}$. The cell cultures grew slowly with doubling times of 2 to $3 \mathrm{~d}$. One of the cultures, pig inner cell mass-19 (PICM-19), was passaged continuously for over $2 \mathrm{yr}$ [ $>100$ population doublings (PD)] and appears to be an infinitely self-renewing cell population. The stem cell characteristics of the epiblast-derived fetal hepatocytes indicate that the cells may be unique for investigations of liver differentiation and organogenesis.
\end{abstract}

Key words: differentiation; epiblast; hepatocyte; pig; pluripotent.

\section{INTRODUCTION}

The continuous secondary culture of normal parenchymal hepatocytes has not been possible (Williams et al., 1977; Guguen-Guillouzo et al., 1983; Perraud et al., 1991). In vitro hepatocyte studies have largely been limited to primary cultures of hepatocytes established after collagenase perfusion of rat or mouse livers (Williams et al., 1977; Berry and Friend, 1969). These techniques were also amenable to the establishment of primary hepatocyte cultures in nonrodent species such as the pig (Caperna et al., 1985). The use of primary cultures is problematic because it is labor intensive and inherently variable. Also, other epithelial cells, fibroblasts, and macrophages were common "contaminants" in primary liver cell culture and these cells can quickly overgrow or otherwise interfere with experimental manipulations and measurements (Caperna et al., 1985; Furukawa et al., 1987; Langenbach et al., 1979). In addition, normal liver parenchymal cell activities such as $\alpha$-fetoprotein production, albumin production, and various enzymatic functions were often lost within 1 to $2 \mathrm{wk}$ of establishment in primary culture (Guguen-Guillouzo et al., 1983; Langenbach et al., 1979). An alternative to normal parenchymal hepatocyte cell culture has been the establishment of numerous human and rodent hepatocarcinoma

\footnotetext{
${ }^{1}$ To whom correspondence should be addressed.

${ }^{2}$ Visiting scientist from the Irene Animal Production Institute, South Africa.
}

derived cell lines (Richardson et al., 1969; Aden et al., 1979). Although several of these hepatoma cell lines were minimally deviated and expressed various proteins representative of normal hepatocyte function, they are likely to be abnormal in several aspects, particularly growth control. For example, some of these cell lines were highly tumorigenic when placed in vivo (Richardson et al., 1969; Knowles et al., 1980). Also, while hepatocyte growth factor (HGF) is mitogenic for primary hepatocytes, it has been reported to be cytostatic for the hepatoma cell lines HepG2, Hep3B, and H35 (Higashio and Shima, 1993). Some human hepatoma cell lines also chronically produced hepatitis proteins (Aden et al., 1979; Knowles et al., 1980). Thus, hepatoma derived cell cultures may confuse assessments of normal parenchymal hepatocyte biology in vitro, and in vivo assessments may not be possible. The ability to sustainably culture normal, functional parenchymal hepatocytes in secondary culture would be novel and of great value for the routine study of hepatocyte biology.

It was hypothesized that the liver contains stem cells that support its general long-term function, and its regenerative ability (reviewed in Sigal et al., 1992, and Fausto and Meade, 1989). Stem cells were not identified although embryonic phenotypic gene expression (e.g., $\alpha$-fetoprotein) was found in some proliferating liver epithelia following the administration of hepatotoxic agents (Fausto et al., 1987; Evarts et al., 1987). Liver "oval" cells and intrahepatic bile duct cells were proposed as candidate liver stem cells or facultative stem cells (reviewed in Sigal et al., 1992, and Fausto and Meade, 




Fig. 1. Hepatocytelike morphology and differentiation of PICM cells in STO co-culture. A, PICM-35, Passage 7, Oil Red O stained (19) after 3 weeks in static culture with differentiation into open lumen ductal structures (small arrows) and intracellular and extracellular accumulations of lipid (large arrows, red staining). Bar $=42 \mu \mathrm{m} . B$, PICM-19, Passage 39, with ductal formations without an open lumenal space but with collected secretory material (arrows) after 2 wk in static culture. Bar $=28 \mu \mathrm{m}$. C, PICM-19, Passage 5, in monolayer with biliary canaliculilike structures between cells (arrows) after $2 \mathrm{wk}$ in static culture. Bar $=28 \mu \mathrm{m}$. D, Oil Red $\mathrm{O}$ stained (19) colony of NIH/3T3 cells undergoing adipogenesis (Blondel et al., 1990). Bar $=42 \mu \mathrm{m}$. 

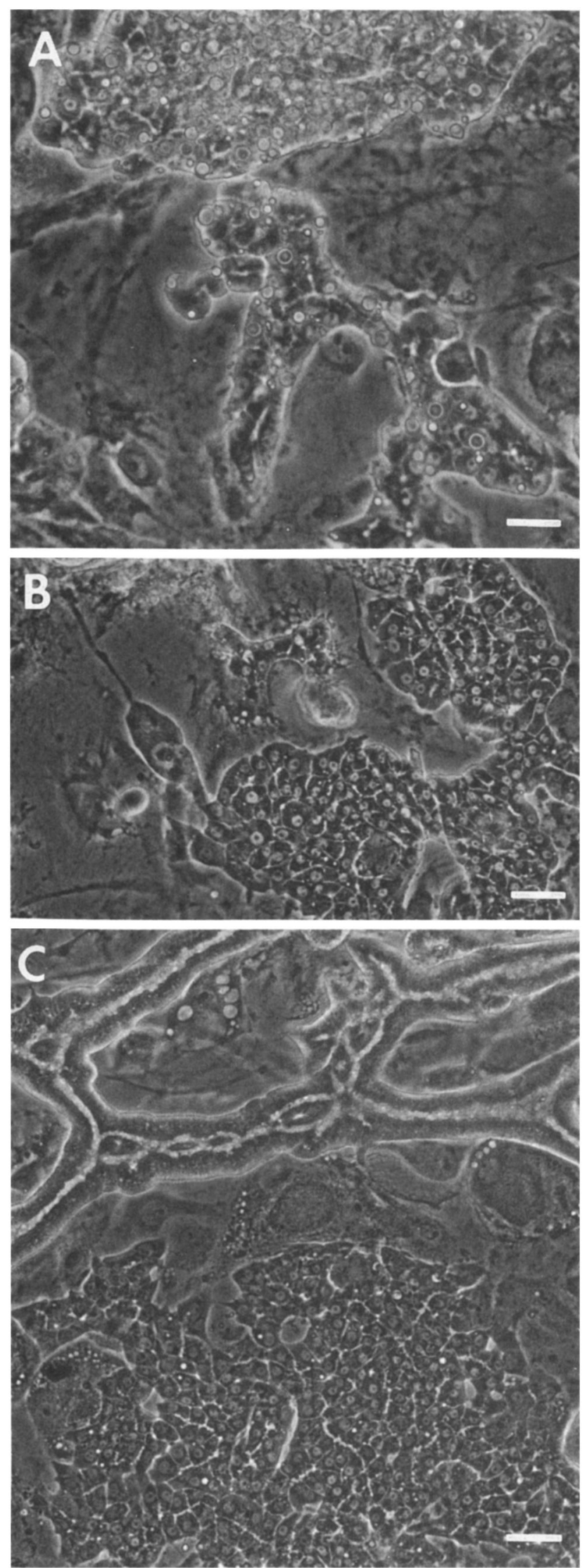

Fig. 2. Hepatocytelike morphology and differentiation of PICM cells in
1989). A consensus of data indicated that liver stem cells would express $\alpha$-fetoprotein and albumin and would be capable of differentiating into bile duct cells and parenchymal hepatocytes (Shiojiri, 1981; Evarts et al., 1989; Germain et al., 1988).

In this study, we describe the characterization of sustainable cultures of secretory epithelium derived from the 8-day pig epiblast, which have the attributes of pluripotent fetal hepatocytes. Mammalian preimplantation blastocysts contain an anatomically and developmentally discrete group of cells termed the primitive ectoderm or epiblast. Epiblast cells are totipotent and give rise to the somatic and germ cells of the body (reviewed in Beddington, 1986). We recently demonstrated that isolated pig epiblasts produced numerous differentiated cell types that could be grown into mass cultures (Talbot et al., 1993). One cell type was epithelial and differentiated into ductal structures or polygonal hepatocytelike cells in vitro (Talbot et al., 1993). The further characterization of this epithelium, exemplified by a cell culture designated as PICM-19, demonstrates the cells' expression and secretion of hepato-specific proteins.

\section{Materials AND MethodS}

Cell culture. The derivation of the PICM-13, -18 , and -19 cell cultures was previously described (Talbot et al., 1993), and PICM-26, -29, -30, $-31,-32$, and -35 were isolated in essentially the same manner except that PICM-35 was derived from a 12-d embryonic disc. PICM cells were grown as previously described (Talbot et al., 1993) on mitomycin C (Sigma, St. Louis, MO) inactivated STO mouse fibroblast feeder cell layers [CRL 1503, American Type Culture Collection (ATCC, Rockville, MD)] plated at $5 \times$ $10^{4}$ cells $/ \mathrm{cm}^{2}$. The culture medium was a 1:1 mixture of Dulbecco's modified Eagle's medium and Medium 199 with $10 \%$ fetal bovine serum (FBS) and antibiotics (10\% DMEM-199+) (GIBCO, Grand Island, NY). Additional supplementation with $\beta$-mercaptoethanol, nonessential amino acids, glutamine, and nucleosides was as described by Robertson (1987). STO and PICM-19 cell cultures have been tested for mycoplasma by Hoechst staining.

Northern blot analysis of PICM-19 cells. The RNA from STO mouse fibroblasts, PICM-16, ST pig testis cell line (CRL 1746 ATCC), 60-d fetal pig liver, adult pig liver, and PICM-19 cells grown in static culture for various periods after passage was analyzed by Northern analysis (Fourney et al., 1988). Twenty micrograms of total RNA, prepared as previously described (Chomczynski and Sacchi, 1987), was loaded per lane and transferred to Zetaprobe membrane (Bio-rad, Hercules, CA). The Northern blot was hybridized with ${ }^{32} \mathrm{P}$-labeled cDNA probes to pig AFP (C137) and pig albumin (C230) or pig $\beta$-fibrinogen (C6), kindly provided by Dr. Roger T. Stone (Stone, 1989), followed by autoradiography. Hybridizations with a human glyceraldehyde-3-phosphate dehydrogenase DNA probe (pSP6G3PDH, Ambion, Austin TX) or an $\alpha$-actin DNA probe, kindly provided by Dr. Roger T. Stone, were performed as a mRNA loading control.

Immunoblot analysis of PICM-19 conditioned medium. Serum-free medium [DMEM-199 with HGF $(2 \mathrm{ng} / \mathrm{ml})$, rat tail collagen $(30 \mathrm{mg} / \mathrm{ml})$, and $1 \times \mathrm{MITO}^{+}$serum extender (Collaborative, Bedford, MA)] was conditioned for $3 \mathrm{~d}$ by $50-75 \%$ confluent monolayers of PICM-19 or STO feeder cells alone. Conditioned media samples or diluted pig serum $(1: 50)$ were mixed $1: 1$ with loading buffer containing sodium dodecyl sulfate (SDS) and $\beta$-mercaptoethanol. Samples were loaded onto a $12 \%$ polyacrylamide gel and electrophoresis (PAGE) performed under described conditions (Laemmli, 1970). Proteins were transferred to nitrocellulose $(0.2 \mu)$, blocked with gelatin, and probed with polyclonal antisera. Specific immunoreactive antigens were visualized with alkaline phosphatase conjugated secondary antibody reagents (Sigma).

TGF $\beta$ inhibition of PICM-19 cells. PICM-19 cells were plated at $1 \times$ $10^{5}$ cells $/ \mathrm{cm}^{2}$ in 4 -well plates with $1.9 \mathrm{~cm}^{2}$ well surfaces (Nunc, Denmark) that had been previously seeded with $5 \times 10^{4}$ mitomycin-treated STO cells per $\mathrm{cm}^{2}$ (Talbot et al., 1993). Porcine TGF $\beta 1$ (R\&D Systems, Minneapolis,

STO co-culture. A, PICM-30, Passage 6, note lipid accumulation. Bar $=28$ $\mu \mathrm{m}$. B, PICM-35, Passage 8. Bar $=42 \mu \mathrm{m}$. C, PICM-45, Passage 6, note ductal formation. Bar $=42 \mu \mathrm{m}$. 


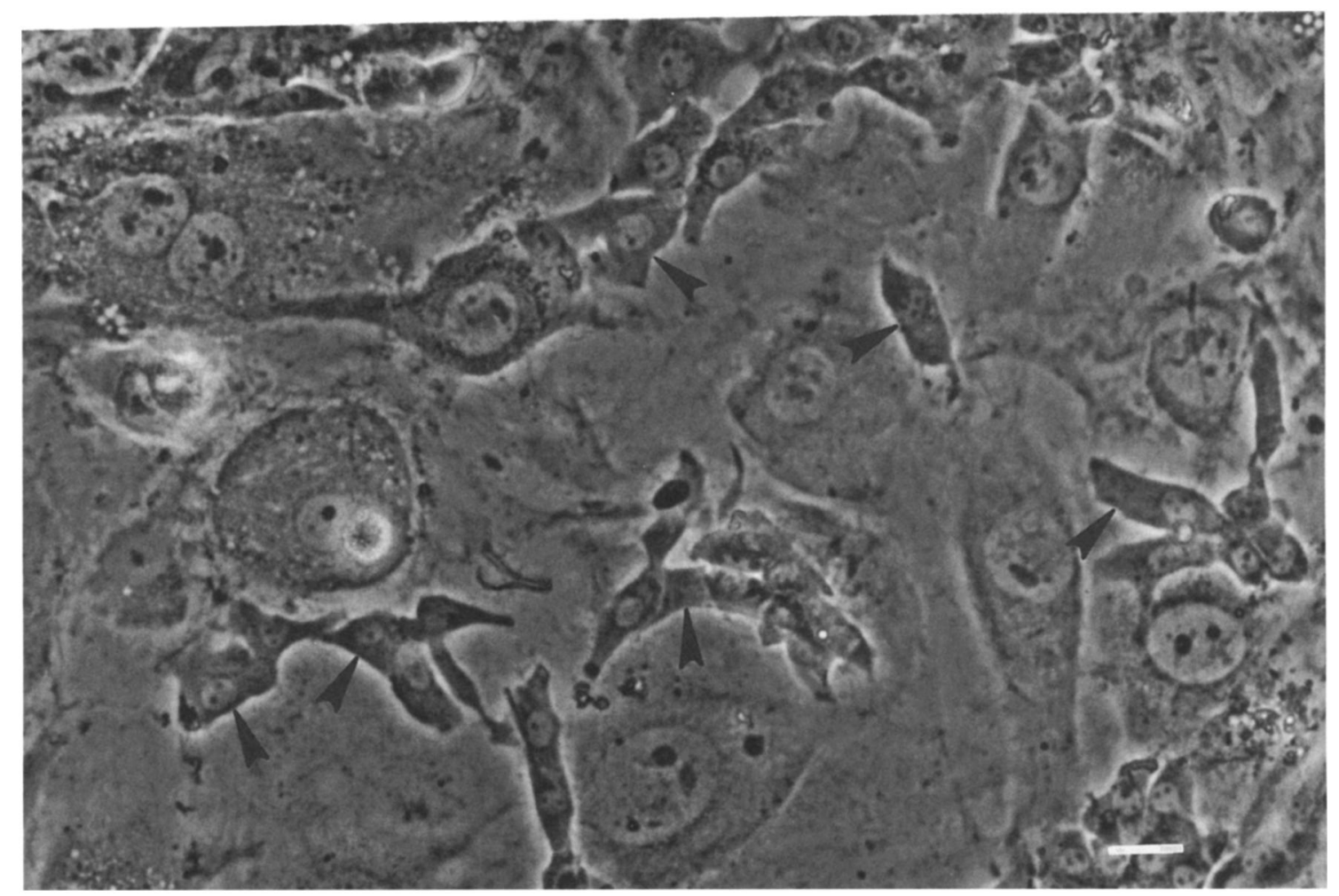

FIG. 3. Morphology of recently passaged, subconfluent, undifferentiated PICM-19 cells in STO co-culture. Passage 26; arrows indicate PICM-19 cells. Bar $=23 \mu \mathrm{m}$.

MN) was added at the indicated concentrations in 10\% DMEM-199 (+) at input and every 48-72 $\mathrm{h}$ with refeedings. Cells were harvested after $7 \mathrm{~d}$ by trypsin-EDTA treatment and counted on a hemacytometer from 4 independent wells for each treatment. Cell counts were analyzed by ANOVA. Signifcant differences from control wells were determined by Dunnetts "T" procedure (asterisk).

\section{Results}

Hepatocytelike morphology and differentiation of PICM cells. The PICM-19 cell culture displayed a morphology typical of primary cultured parenchymal hepatocytes (Berry and Friend, 1969; Caperna et al., 1985; Furukawa et al., 1987). The cells were polygonal with well-defined cell boundaries. Under phase-contrast microscopy they had dark, granular cytoplasm with large, distinct nuclei and nucleoli (Figs. $1 C, 2$, and 3). Only mononuclear cells were observed. Previously, fetal and neonatal parenchymal hepatocytes were described as mononuclear whereas primary cultures of adult hepatocytes usually contained binuclear cells (Caperna et al., 1985; Juan et al., 1992). Preliminary karyotype analysis of PICM-19 also showed no evidence of polyploidy and confirmed the porcine origin of the cells (data not shown). The independent isolation from 8-d pig epiblasts of continuous cultures similar or identical to the PICM19 culture was accomplished about a dozen times (Fig. 2 and Talbot et al., 1993). All the cell cultures shared the ability to form multicellular duct-like structures, develop spaces between individual cells similar to biliary canaliculi, or accumulate and secrete lipid (Fig. $1 A, B, C$ and Fig. 2). The ductal and adipogenic differentiation phenotypes appeared to be mutually exclusive and occurred spontaneously over the course of 1 to $3 \mathrm{wk}$ in static co-culture on STO feeder layers. The recently passaged, individual, undifferentiated PICM-19 cells had a similar but somewhat stellate morphology (Fig. 3).

Other investigators found that in primary parenchymal hepatocytes cultures, small biliary canaliculi often developed within the monolayers (Furukawa et al., 1987; Barth and Schwartz, 1982). Likewise, small canaliculi of the same size and character developed in the monolayers of the PICM-19 cells (Fig. 1 C). Once formed, canaliculi were stable and their associated cells could retain their large polygonal shape for weeks without significant change. However, canaliculi were also observed in areas of the monolayer that eventually proceeded to duct formation and adipogenesis. As can be seen at the top of Fig. $1 C$, individual canaliculi coalesced to form longer networks of interconnected canaliculi. Final differentiation into a mature ductal structure appeared to occur from these interconnected canaliculi. Duct formation was a terminal differentiation event because the constituent cells would no longer divide and grow if passaged, although they remained viable. Similarly, cultures that differentiated to adipogenesis grew very slowly when passaged and could not be sustainably cultured. In contrast, colonial areas that developed small canaliculi could be cloned and passaged to produce mass cultures without loss of differentiation potential. Thus, the development of canaliculi was nonterminal differentiation, which could be a precursor to the terminal ductal or adipogenic differentiation programs.

Phase-contrast microscopy of the fully differentiated duct-like structures showed phase-dense material at the lumenal surface of the structures (Fig. $1 \mathrm{~A}$ ). This arrangement indicates a secretory structure. A modified form of the duct-like differentiation structure 
occurred in the PICM-19 culture after about 50 PD. This formation was characterized by the absence of a lumenal space. Instead, the duct-like structures were closed with the cells assuming a distinct columnar arrangement. Heavy deposits of secretory matter appeared between the juxtaposed cells over a period of 2 to $3 \mathrm{wk}$ in static culture (Fig. $1 B$ ).

Primary cultures of rodent parenchymal hepatocytes sometimes accumulated lipid, consistent with their lipogenic in vivo function (Richardson et al., 1969; Michalopoulos et al., 1982). PICM-18, $-19,-26,-29$, and -35 produced colonies that stained intensely with Oil Red $\mathrm{O}$ (Fig. $1 \mathrm{~A}$ ) indicating lipid sequestration. Although adult porcine liver was not shown to synthesize and accumulate fatty acids, the enzymatic machinery for de novo fatty acid synthesis is present (Mersmann, 1986). The production of triglycerides by the epiblast-derived hepatocytelike cultures may result from the embry-
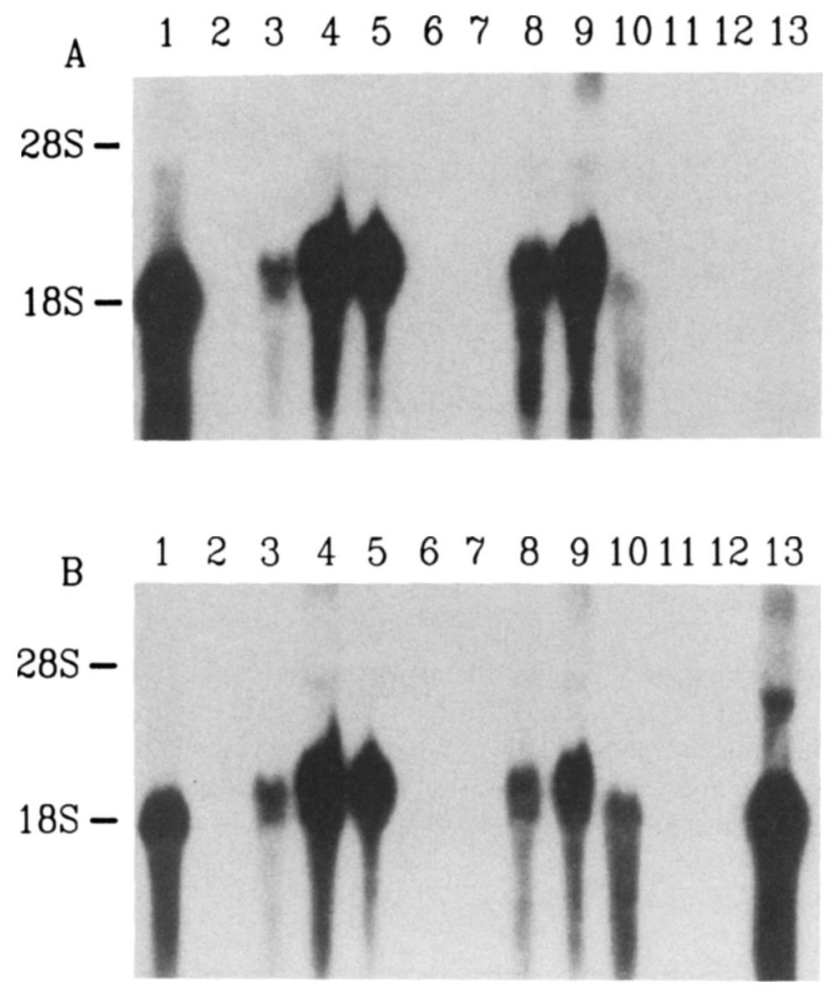

C

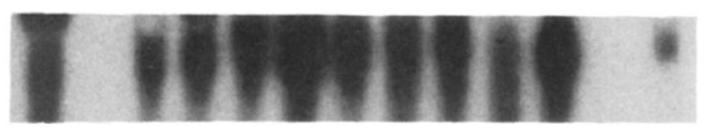

FIG. 4. Northern blot analysis of PICM-19 $\alpha$-fetoprotein and albumin mRNA expression. The Northern blot was hybridized successively with ${ }^{32} \mathrm{P}$ labeled cDNA probes for $A$, pig $\alpha$-fetoprotein $(\mathrm{C} 137)$ and $B$, pig albumin (C230), followed by autoradiography. Arrows indicate the positions of $28 \mathrm{~S}$ and I8S RNA. Both eĐNA probes detected a single band approximately 2 $\mathrm{kb}$ in length. Hybridization with a human glyceraldehyde-3-phosphate dehydrogenase DNA probe (PSP6-G3PDH, Ambion) was performed as an mRNA loading control $(C)$. A single band of approximately $1.4 \mathrm{~kb}$ was detected by the G3PDH probe. In vivo fetal liver, lane 1; blank, lane 2; PICM-19, Passage 32, at 7, 15, and 23 d post-passage, lanes 3,4 and 5, respectively; ST pig testis cell line, lane 6; PICM-16 (Talbot et al., 1993), lane 7; PICM-19, Passage 33, at 12, 19, and $31 \mathrm{~d}$ post-passage, lanes 8, 9 and 10, respectively; STO embryonic mouse fibroblasts, lane 11; blank, lane 12; and in vivo adult liver, lane 13.
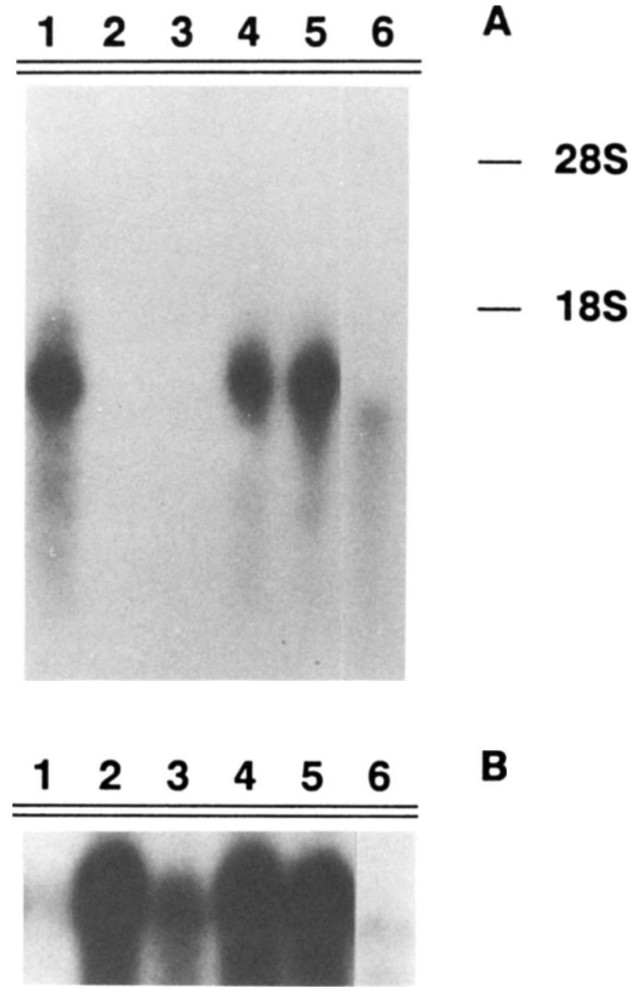

Fig. 5. Northern blot analysis of PICM-19 $\beta$-fibrinogen mRNA expression. $A$, The Northern blot was hybridized with a ${ }^{32} \mathrm{P}$-labeled cDNA probe to pig $\beta$-fibrinogen (C6), followed by autoradiography. $B$, Hybridization with an $\alpha$-actin DNA probe was performed as an mRNA loading control. The $\beta$-fibrinogen probe detected a single band of approximately $1.6 \mathrm{~kb}$ in length and the $\alpha$-actin probe detected a single band of $1.8 \mathrm{~kb}$. Arrows indicate the positions of $28 \mathrm{~S}$ and 18S RNA. In vivo adult pig liver, lane 1; ST pig testis cell line, lane 2; Mitomycin C treated STO mouse embryonic fibroblasts, lane 3; PICM-19, passage 33, 15-d post-passage, lane 4, PICM-19, passage 33, 23-d post-passage, lane 5; and in vivo 26-d fetal pig liver, lane 6.

onic nature of the cells or the in vitro culture conditions (i.e., presence/lack of specific hormonal stimuli or possibly basic medium components). The lipid appeared to be actively secreted from the cells since large globules of lipid were often present in the extracellular matrix above the cells to the extent that the cells could no longer be clearly discerned. In contrast, lipid accumulation typically seen in certain fibroblast cultures, such as mouse 3T3 adipocytes, was cell bound, and the cells were prone to detach and float off the substrate because of the buoyancy of the lipid (Fig. $1 D$ ). The firm anchorage of the epiblast-derived hepatocytelike cells undergoing lipid accumulation probably reflects an interconnective cytoskeleton network typical of cultured epithelial cells in general and of parenchymal hepatocytes specifically (Osborn and Weber, 1982; Marceau et al., 1985; Levy et al., 1988).

PICM-19 liver specific mRNA expression. It was previously demonstrated that porcine parenchymal hepatocytes expressed a variety of genes characteristic of liver function, such as $\alpha$-fetoprotein (AFP), albumin, and $\beta$-fibrinogen (Stone, 1989). AFP and albumin in particular are diagnostic for fetal hepatocyte character since AFP expression was restricted to fetal livers (Stone, 1989). Moreover, albumin and AFP are expressed during various early stages of hepatic stem cell development (Sigal et al., 1992). Total RNA of PICM-19 cells (Passage 33) was assayed by Northern blot, and high 


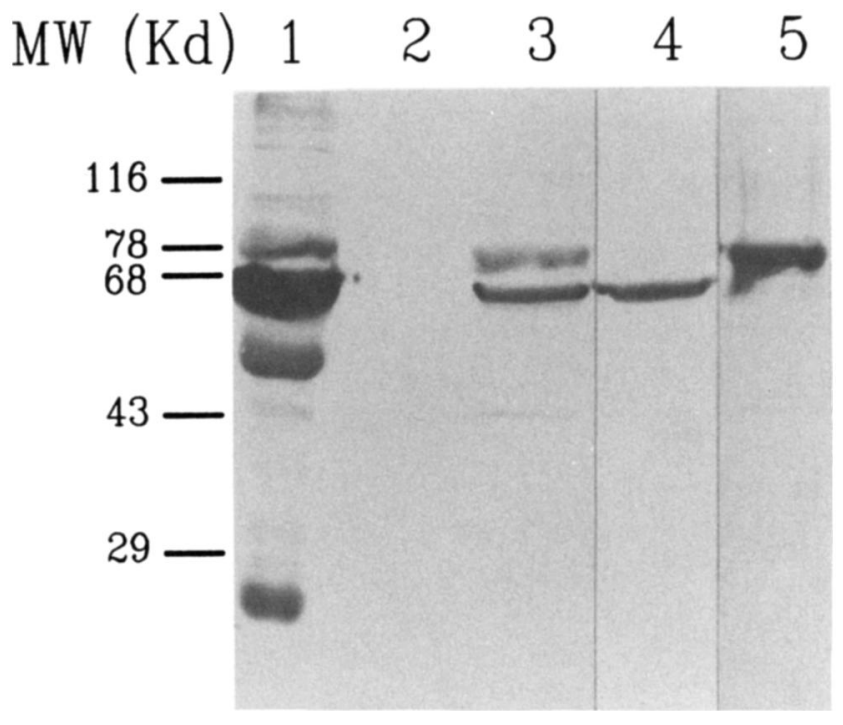

FIG. 6. Immunoblot analysis of PICM-19 transferrin and albumin secretion. Anti-whole pig serum (lanes 1, 2 and 3), anti-pig albumin (lane 4), and anti-pig transferrin (lane 5). Adult pig serum, lane 1; STO embryonic mouse fibroblast conditioned medium, lane 2; PICM-19 conditioned medium, lanes 3,4 and 5 .

levels of AFP, albumin (Fig. 4), and $\beta$-fibrinogen (Fig. 5) mRNA were detected. The expression of albumin and AFP was minimal in cultures that had recently been passaged (Fig. 4 lanes 3 and 8 ). The expression of AFP and albumin reached a peak in PICM-19. cultures that had remained in static culture for 2 to $3 \mathrm{wk}$ and that had extensively differentiated into ductal structures and monolayers containing biliary canaliculi between the cells (Fig. 4 lanes 4 and 9). A relatively high expression was maintained in culture for an additional 1-2 wk, although some loss of the AFP and albumin signal was seen after longer periods in culture (Fig. 4 lanes 5 and 10). This may have resulted from insufficient refeeding of the very dense cultures. Total RNA preparations from fetal and adult pig liver demonstrated that, as expected, AFP expression was restricted to fetal liver while albumin and $\beta$-fibrinogen expression were found in both fetal and adult livers (Fig. 4 lanes 1 and 13; Fig. 5). A pig testis epithelial cell line, an epiblast-derived epithelial cell line, PICM-16, analogous to MDCK epithelial cells (manuscript in preparation), and STO feeder cells were all negative for AFP and albumin mRNA expression (Fig. 4 lanes 6, 7, and 11). The expression profile is consistent with PICM-19 cells being fetal hepatocytes (Stone, 1989).

PICM-19 liver specific protein secretion. PICM-19 secreted large amounts of transferrin, AFP, and albumin into the culture medium. Serum-free culture medium was conditioned for $3 \mathrm{~d}$ by 50-75\% confluent monolayers of PICM-19 (Passage 55) grown for 2 to $3 \mathrm{wk}$ in static culture. Coincident STO feeder cells alone were compared as a control for STO cell secretory activity and for nonspecific protein residues remaining from the initial 10\% FBS culture of the cells. The unconcentrated conditioned media were analyzed by SDS-PAGE and immunoblotting (Figs. 6 and 7). PICM-19 cells secreted several proteins that crossreacted with an antisera to whole pig serum (Fig. 6 lane 3). The prominent protein bands were subsequently identified as albumin, AFP, and transferrin based on apparent molecular weight and crossreactivity with

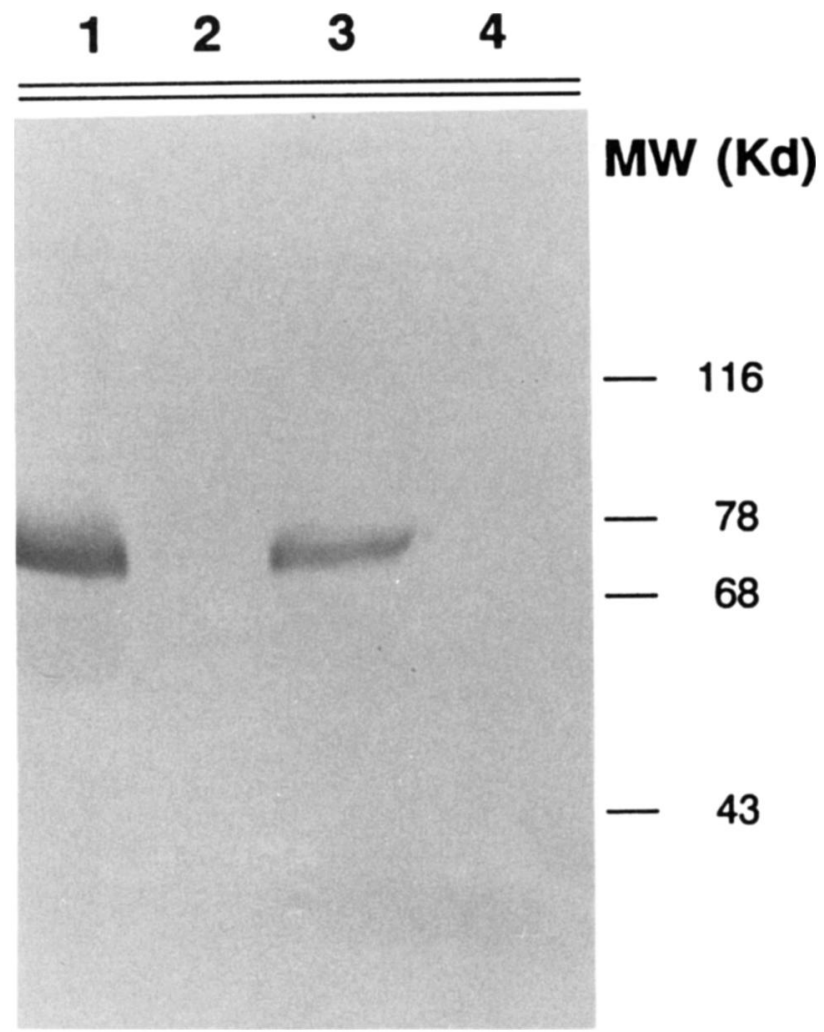

Fic. 7. Immunoblot analysis of PICM-19 $\alpha$-fetoprotein (AFP) secretion. The Western blot was reacted with anti-pig AFP antibody. Ninety-day fetal pig serum, lane 1; adult pig serum, lane 2; PICM-19, Passage 55, conditioned medium, lane 3; STO mouse embryonic fibroblast conditioned medium, lane 4.

specific antisera to porcine albumin, transferrin (Fig. 6 lanes 4 and 5), and AFP (Fig. 7 lane 3). In contrast, the STO feeder cell conditioned medium showed little or no reaction with the antibodies (Fig. 6 lane 2; Fig. 7 lane 4) demonstrating that the transferrin, AFP, and albumin resulted from PICM-19 secretory activity.

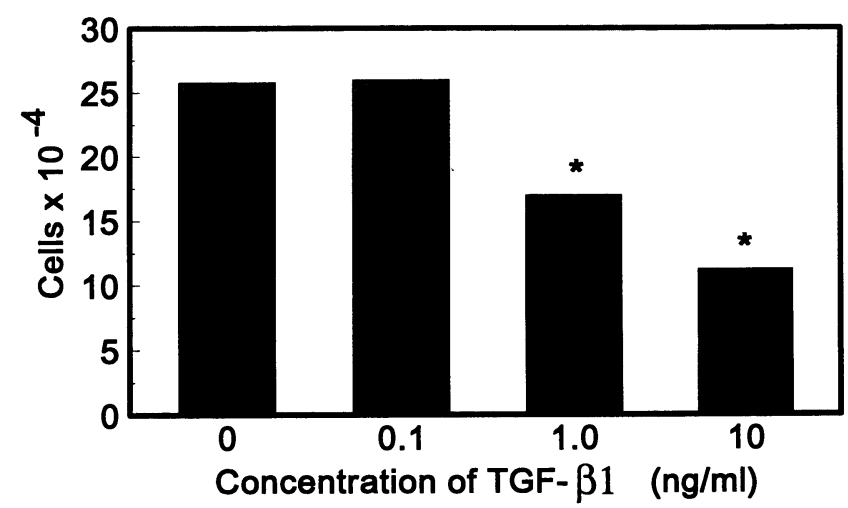

FIG. 8. TGF $\beta 1$ inhibition of PICM-19 cell growth and viability. Cell counts were analyzed by ANOVA. Significant differences from control wells were determined by Dunnetts " $T$ " procedure (asterisk). At $0.1 \mathrm{ng} / \mathrm{ml}$ the effect on PICM-19 cell growth and viability was no different $(P>0.05)$ from that of the control medium not containing TGF $\beta 1$. 
TGF $\beta 1$ inhibition of PICM-19 cell growth and viability. DNA synthesis in adult rat parenchymal hepatocytes was shown to be inhibited by TGF $\beta$ (Nakamura et al., 1985; Carr et al., 1986). Addition of porcine TGF $\beta 1$ inhibited the growth and viability of the PICM-19 cells (Fig. 8). PICM-19 cells that survived TGF $\beta 1$ (1 $\mathrm{ng} / \mathrm{ml}$ ) treatment for $7 \mathrm{~d}$ were enlarged, flattened, and elongated (not shown). Continued incubation with TGF $\beta 1(1 \mathrm{ng} / \mathrm{ml})$ for 2 to 3 wk resulted in the complete loss of the PICM-19 cells from the culture as judged by microscopic observation. The hepatocytelike PICM-26, -29 , and -32 cell cultures were also exposed to TGF $\beta 1$ at $2 \mathrm{ng} / \mathrm{ml}$ and were similarly inhibited.

PICM-19 cells retain hepatocyte form and function for over 2 years. Parenchymal hepatocytes are not easily sustained in culture (Guguen-Guillouzo, 1983; Perraud et al., 1991; Tong et al., 1992). The PICM cells were strictly feeder-dependent and senesced if plated at split ratios higher than 1:5 off feeder cells. The PICM cells grew on top of or intermingled with the feeder-layer cells (Figs. 1, 2 and 3), and all the cultures grew slowly. PICM-19 had a doubling time of approximately $72 \mathrm{~h}$ by standard culture enumeration and by counting the cells of individual colonies (data not shown). PICM-19 has been in continuous culture for over $2 \mathrm{yr}$, representing over $100 \mathrm{PD}$, assuming a $100 \%$ plating efficiency at each passage. Over the course of this period, single-cell cloning of PICM-19 was performed at least six times with the establishment of mass cultures of the subclones. The differentiation potential of the cells did not change over the passage history of the PICM-19 culture. The subclones of PICM-19 also retained the ability to form canaliculi and ductal structures and to accumulate cellular and extracellular lipid. Although some epithelial cell cultures were very long-lived in secondary culture (Martin et al., 1970; Rheinwald and Green, 1977), it is possible that the PICM-19 cell culture is an infinitely self-renewing cell population (i.e., a cell line).

The morphology of the undifferentiated PICM-19 cells remained the same with no signs of senescence during the continuous culture or subclonings. However, one single cell cloned culture, PICM-19 clone $3 \mathrm{~B}$, appeared to undergo spontaneous transformation in its ductal cell compartment. At approximately 120 total PD some of the cells forming ductal structures lost growth control and took over the culture after subsequent passage. The nature of this variant cell is under investigation.

\section{Discussion}

The PICM-19 cell culture was derived by co-culture on STO feeder cells. STO feeder cells were shown to provide an environment suitable for the isolation and maintenance of hepatocarcinoma cells (Aden et al., 1979), mouse embryonic stem cells (Robertson, 1987), and mouse primordial germ cells (Matsui et al., 1992; Resnick et al., 1992). The STO feeder cells were shown to produce a variety of growth factors (Robertson, 1987; Matsui et al., 1992; Schmitt et al., 1991; Montesano et al., 1991a; Montesano et al., $1991 \mathrm{~b}$; Hilton et al., 1991). Some of these were mediators of hepatocyte growth and function such as leukemia inhibitory factor (LIF) and hepatocyte growth factor (HGF) (Montesano et al., 1991a; Montesano et al., 1991b; Hilton et al., 1991). Hepatocytes were shown to express receptors for both LIF and HGF (Hilton et al., 1991; Prat et al., 1991). LIF was reported to induce acute phase response proteins in hepatocytes (Baumann and Wong, 1989), and HGF has been widely described as a potent hepatocyte mitogen (Zarnegar and Michalopoulos, 1989; Strain et al., 1991; Nakamura et al., 1984). Both LIF and HGF stimulated $(P>0.05)$ replication of PICM-19 cells when assayed in a 5\% FBS and reduced STO feeder cell environment (manuscript in preparation). Thus, two growth factors directly related to hepatocyte growth and function are present in the STO feeder layer and may support the development and growth of hepatocytes from the primary epiblast culture.

The PICM-19 cell culture's establishment in secondary culture does not reflect some characteristic of vitality that is peculiar to their epiblast source. The STO co-culture also supported the cultivation of hepatocytes from the 26-d pig fetal liver (manuscript submitted, Talbot et al., 1994). These cell cultures formed monolayers of polygonal cells with interconnective canaliculi that could differentiate further to produce extracellular lipid or multicellular ductal structures (manuscript submitted, Talbot et al., 1994). However, the fetal liver-derived hepatocyte cultures were finite and senesced after variable degrees of in vitro passage. Thus, epiblast culture may enable a derivation of fetal hepatocytes prior to differentiation into committed progenitor cells.

The PICM-19 cell culture may represent the in vitro equivalent of the putative hepatic stem cell because of the following:

1. PICM-19 was derived from epiblast cells, the source of all stem cells in the body.

2. PICM-19 cells have a fetal phenotype as expected of hepatic stem cells (Sigal et al., 1992).

3. The long-term continuous passage of the PICM-19 cell culture without loss of differentiation potential is indicative of a stem cell population.

4. The ability of the PICM-19 cells to differentiate into three phenotypes (multicellular ductal structures, polygonal cells with biliary canaliculi, and adipogenic cells) logically connected with liver form and function is consistent with expected hepatic stem cell character (Sigal et al., 1992; Fausto and Meade, 1989). Experiments to test the ability of PICM-19 cells to populate and function in the liver are planned and may provide a measure of the extent of their stem cell character.

The PICM-19 cells may be useful as an in vitro model for fetal hepatocyte functions and differentiation. They may also prove useful in experimentation on extracorporeal liver devices, artificial organ construction, gene therapy, and, possibly, malaria and hepatitis research. The derivation of the PICM hepatocyte cultures from the pig epiblast demonstrates the possibility of deriving specialized cell types from any mammalian epiblast.

\section{ACKNOWLEDGMENTS}

We thank Dr. Roger Stone for providing the cDNA probes to pig $\alpha$-fetoprotein, pig albumin, and pig $\beta$-fibrinogen, for anti-pig AFP antibody, and for critical reading of the manuscript. We also thank Dr. M. L. Failla and Dr. Linda K. Hansen for their reviews and suggestions on the manuscript, and Ms. Linda Neuenhahn for preparing the final typescript.

\section{REFERENCES}

Aden, D. P.; Fogel, A.; Plotkin, S., et al. Controlled synthesis of HBsAg in a differentiated human liver carcinoma-derived cell line. Nature (London) 282:615-616; 1979.

$\rightarrow$ Barth, C. A.; Schwartz, L. R. Transcellular transport of fluorescein in hepatocyte monolayers: evidence for functional polarity of cells in culture. Proc. Natl. Acad. Sci. USA 79:4985-4987; 1982.

Baumann, H.; Wong, G. G. Hepatocyte-stimulating factor III shares structural and functional identity with leukemia-inhibitory factor. J. Immunol. 143:1163-1167; 1989.

Beddington, R. Analysis of tissue fate and prospective potency in the egg 
cylinder. In: Rossant, J.; Pederson, R. A., eds. Experimental approaches to mammalian embryonic development. Cambridge: Cambridge University Press; 1986:121-147.

$\rightarrow$ Berry, M. N.; Friend, D. S. High yield preparation of isolated rat liver parenchymal cells. A biochemical and fine structural study. J. Cell Biol. 43:506-520; 1969.

Blondel, B.; Talbot, N.; Merlo, G. R., et al. Efficient induction of focus-formation in a subclone of NIH 3T3 cells by c-myc and its inhibition by serum and by growth factors. Oncogene 5:857-865; 1990.

Caperna, T. J.; Failla, M. L.; Kornegay, E. T., et al. Isolation and culture of parenchymal and nonparenchymal cells from neonatal swine liver. J. Anim. Sci. 61:1576-1586; 1985.

Carr, B. I.; Hayashi, I.; Branum, E. L., et al. Inhibition of DNA synthesis in rat hepatocytes by platelet-derived type transforming growth factor. Cancer Res. 46:2330-2334; 1986.

$\rightarrow$ Chomczynski, P.; Sacchi, N. Single step method of RNA isolation by acid guandinium thiocyanate-phenol-chloroform extraction. Anal. Biochem. 162:156-159; 1987.

Evarts, R. P.; Nagy, P.; Marsden, E., et al. A precursor-product relationship exists between oval cells and hepatocytes in rat liver. Carcinogenesis 8:1737-1740; 1987.

Evarts, R. P.; Nagy, P.; Nakatsukasa, H., et al. In vivo differentiation of rat liver oval cells into hepatocytes. Cancer Res. 49:1541-1547; 1989.

Fausto, N.; Meade, J. E. Biology of disease. Regulation of liver growth protooncogenes and transforming growth factors. Lab. Invest. $60: 4-13 ; 1989$.

Fausto, N.; Thompson, N. L.; Braun, L. Purification and culture of oval cells from rat liver. In: Pretlow, T. G., II; Pretlow, T. P., eds. Cell separation: methods and selected applications. Vol. 4. Orlando: Academic Press; 1987:45-77.

Fourney, R. M.; Miyakoshi, J.; Day, R. S., et al. Northern blotting: efficient RNA staining and transfer. Focus 10:5-7; 1988.

Furukawa, K.; Shimida, T.; England, P., et al. Enrichment and characterization of clonogenic epithelial cells from adult rat liver and initiation of epithelial cell strains. In Vitro Cell. Dev. Biol. 23:339-348; 1987.

Germain, L.; Blouin, M. J.; Marceau, N. Biliary epithelial and hepatocytic cell lineage relationship in embryonic rat liver as determined by the differential expression of cytokeratins, alpha-fetoprotein, albumin and cell surface-exposed components. Cancer Res. 48:4909$4918 ; 1988$.

Guguen-Guillouzo, C.; Clement, B.; Baffet, G., et al. Maintenance and reversibility of active albumin secretion by adult rat hepatocytes co-cultured with another liver epithelial cell type. Exp. Cell Res. 143:47-54; 1983.

Higashio, K.; Shima, N. Tumor cytotoxicity activity of HGF-SF. Executive Skills 65:351-368; 1993 .

Hilton, D. J.; Nicola, N. A.; Metcalf, D. Distribution and comparison of receptors for leukemia inhibitory factor on murine hemopoietic and hepatic cells. J. Cell Physiol. 146:207-215; 1991.

Juan, C.; Benito, M.; Alvarez, A., et al. Differential proliferative response of cultured fetal and regenerating hepatocytes to growth factors and hormones. Exp. Cell Res. 202:495-500; 1992.

$\rightarrow$ Knowles, B. B.; Howe, C. C.; Aden, D. P. Human hepatocellular carcinoma cell lines secrete the major plasma proteins and hepatitis B surface antigens. Science 209:497-499; 1980.

Laemmli, U. K. Cleavage of structural proteins during the assembly of the head of bacteriophage T4. Nature 277:680-685; 1970.

Langenbach, R.; Malick, L.; Tompa, A., et al. Maintenance of adult rat hepatocytes on $\mathrm{C} 3 \mathrm{H} / 10 \mathrm{~T}^{1} / 2$ cells. Cancer Res. 39:3509-3514; 1979.

Levy, R.; Czernobilsky, B.; Geiger, B. Subtyping of epithelial cells of normal and metaplastic human uterine cervix, using polypeptide-specific cytokeratin antibodies. Differentiation 39:185-196; 1988.

Marceau, M.; Baribault, H.; Leroux-Nicollet, I. Dexamethasone can modulate the synthesis and organization of cytokeratin in cultured differentiating rat hepatocytes. Can. J. Biochem. Cell Biol. 63:448-457; 1985.

Martin, G. M.; Sprague, C. A.; Epstein, C. J. Replicative life-span of cultivated human cells. Effect of donor's age, tissue and genotype. Lab. Invest 23:86-92; 1970.
Matsui, Y.; Zsebo, K.; Hogan, B. L. M. Derivation of pluripotential embryonic stem cells from murine primordial germ cell in culture. Cell 70:841-847; 1992.

Mersmann, H. J. The pig as a model for aberrations associated with carbohydrate and lipid metabolism. In: Tumbleson, M. E., ed. Swine in biomedical research. Vol. 2. New York: Plenum Press; 1986:981995.

Michalopoulos, G.; Cianciulli, H. D.; Novotny, A. R., et al. Liver regeneration studies with rat hepatocytes in primary culture. Cancer Res. 42:4673-4682; 1982.

Montesano, R.; Matsumoto, K.; Nakamura, T., et al. Identification of a fibroblast-derived epithelial morphogen as hepatocyte growth factor. Cell 67:901-908; 1991a.

Montesano, R.; Schaller, G.; Orci, L. Induction of epithelial tubular morphogenesis in vitro by fibroblast-derived soluble factors. Cell 66:697-711; 1991b.

Nakamura, T.; Nawa, K.; Ichihara, H. Partial purification and characterization of hepatocyte growth factor from serum of hepatectomized rats. Biochem. Biophys. Res. Commun. 122:1450-1459; 1984.

Nakamura, T.; Tomita, Y.; Hirai, R., et al. Inhibitory effect of transforming growth factor- $\beta$ on DNA synthesis of adult rat hepatocytes in primary culture. Biochem. Biophys. Res. Commun. 133:1042-1060; 1985.

Osborn, M.; Weber, K. Intermediate filaments: cell-type specific markers in differentiation and pathology. Cell 31:303-306; 1982.

Perraud, F.; Dalemans, W.; Gendrault, J. L., et al. Characterization of trans-immortalized hepatic cell lines established from transgenic mice. Exp. Cell Res. 195:59-65; 1991.

Prat, M.; Narsimhan, R. P.; Crepaldi, T., et al. The receptor encoded by the human c-MET oncogene is expressed in hepatocytes, epithelial cells, and solid tumors. Int. J. Cancer 49:323-328; 1991.

Resnick, J. L.; Bixler, L. S.; Cheng, L., et al. Basic fibroblast growth factor and leukemia inhibitory factor stimulate long-term proliferation of mouse primordial germ cells in culture. Nature 359:550-551; 1992.

Rheinwald, J. G.; Green, H. Epidermal growth factor and the multiplication of cultured human epidermal keratinocytes. Nature 265:421-424; 1977.

$\rightarrow$ Richardson, U. I.; Tashjian, A. H., Jr.; Levine, L. Establishment of a clonal strain of hepatoma cells which secrete albumin. J. Cell Biol. 40:236-247; 1969.

Robertson, E. J. Embryo-derived stem cell lines. In: Robertson, E. J., ed. Teratocarcinomas and embryonic stem cells: a practical approach. Oxford: IRL Press; 1987:71-112.

Schmitt, R. M.; Bruyns, E.; Snodgrass, H. R. Hematopoietic development of embryonic stem cells in vitro: cytokine and receptor gene expression. Genes Dev. 5:728-740; 1991.

Shiojiri, N. The origin of intrahepatic bile ducts in the mouse. J. Embryol. Exp. Morphol. 79:139-152; 1981.

Sigal, S. H.; Brill, S.; Fiorino, A. S., et al. The liver as a stem cell and lineage system. Am. J. Physiol. 263:G139; 1992.

Stone, R. T. Isolation and characterization of recombinant cDNA clones corresponding to developmentally regulated genes in pig liver. J. Anim. Sci. 67:1082-1089; 1989.

Strain, A. J.; Ismail, T.; Tsubouchi, H., et al. Native and recombinant human hepatocyte growth factor are highly potent promoters of DNA synthesis in both human and rat hepatocytes. J. Clin. Invest. 87:1853-1857; 1991.

Talbot, N.; Powell, A.; Pursel, V., et al. Culturing the epiblast cells of the pig blastocyst. In Vitro Cell. Dev. Biol. 29:543-554; 1993.

Talbot, N.; Rexroad, C.; Pursel, V., et al. Colony isolation and secondary culture of fetal porcine hepatocytes on STO feeder cells. in press; 1994.

Tong, J. Z.; Lagausie, P.; Furlan, V., et al. Long-term culture of adult rat hepatocyte spheroids. Exp. Cell. Res. 200:326-332; 1992.

Williams, G. M.; Burmudez, E.; Scarmuzzino, D. Rat hepatocyte primary culture. III. Improved dissociation and attachment techniques and the enhancement of survival by culture medium. In Vitro Cell. Dev. Biol. 13:809-817; 1977.

Zarnegar, R.; Michalopoulos, G. Purification and biological characterization of human hepatopoietin A, a polypeptide growth factor for hepatocytes. Cancer Res. 49:3314-3320; 1989. 